\title{
THE INFLUENCE OF AMBIENT CONDITIONS ON THE PERFORMANCE OF THE THERMOELECTRIC WIRELESS SENSOR NETWORK NODE
}

\author{
UDC 621.362:[004.7:621.39]
}

\author{
Dejan Milić, Aneta Prijić, Ljubomir Vračar, Zoran Prijić \\ University of Niš, Faculty of Electronic Engineering, Niš, Serbia
}

\begin{abstract}
This paper considers the effects of the ambient temperature and unducted air flow on the voltage generated by a thermoelectric generator used to power wireless sensor network node. Structure of the node is simulated using a fully coupled numerical electro-thermal model with convective correlations. Results show that the effect of the ambient temperature is negligible as long as the temperature difference between the hot surface of the node and the ambient is maintained. For natural convection, voltage dependence on the temperature difference can be determined from the open circuit conditions and this can be used to approximate the load conditions. For forced convection, an increase rate of the generated voltage is governed by the thermal resistance of the heatsink and characteristic parameters of the thermoelectric generator.
\end{abstract}

Key words: Thermoelectric generator, Wireless Sensor Node, Energy harvesting

\section{INTRODUCTION}

Wireless sensor network (WSN) nodes powered by harvesting energy from their environment have been a subject of extensive research in the past years. Electricity required to power the nodes is typically obtained by converting solar, mechanical, RF, or thermal energy, therefore harvesters can be roughly grouped as photovoltaic, piezoelectric, RF and thermoelectric, respectively [1]. Energy harvesting eliminates the need for batteries in WSN nodes, thus making them long-lived and suitable for widespread deployment. Such features are particularly desirable for nodes used in systems for environmental monitoring and protection. Among a variety of applications, energy harvesters are employed in the monitoring of air [2], water [3], soil [4, 5], wildlife [6], exhaust gas pipes [7, 8], etc.

One major drawback of WSN nodes powered by energy harvesting is time varying and limited amount of the environmental energy. This requires a careful design of energy conversion and storage circuits as well as optimized management of the power consumption.

Received July 24, 2018 / Accepted November 14, 2018

Corresponding author: Aneta Prijić

University of Niš, Faculty of Electronic Engineering, Aleksandra Medvedeva 14, 18000 Niš, Serbia

E-mail: aneta.prijic@elfak.ni.ac.rs 
The main design goal is to ensure that the node is always supplied by enough power to transmit monitored data, send an alarm, or receive a command. Although various WSN nodes have distinctive internal features, their efficiency is governed primarily by the harvester circuitry, which in turn depends not only on the type of the harvesting but also on the overall environmental conditions.

This paper considers thermal energy harvesting WSN node used as a data logger for temperature monitoring. The energy conversion is performed by thermoelectric generator (TEG), which utilizes Seebeck effect, i.e. the temperature difference between the hot and cold junctions of two materials to produce voltage. In our previous works, we have shown how aluminum core printed circuit boards (PCBs) can be used to improve performances of the WSN node [9], and established guidelines for choosing an appropriate TEG [1012]. However, these considerations were limited to the thermal steady-state case, where there is a fixed ambient temperature, and no air flow over the WSN node. In this paper we extend the analysis by taking into account variations of the ambient temperature and airflow, inevitably present in the real operating environment. Specifically, we investigate their effects on the voltage generated by the TEG.

\section{SYSTEM DESCRIPTION}

The basic elements of the thermal energy harvesting wireless sensor network node are shown in Fig. 1. The commercial thermoelectric module is exploited as a thermoelectric generator to provide power for the node. Two of the external sides of the TEG are kept at different temperatures by exposing it to a heat source at the hot side and enabling the heat release to the ambient at the cold side.

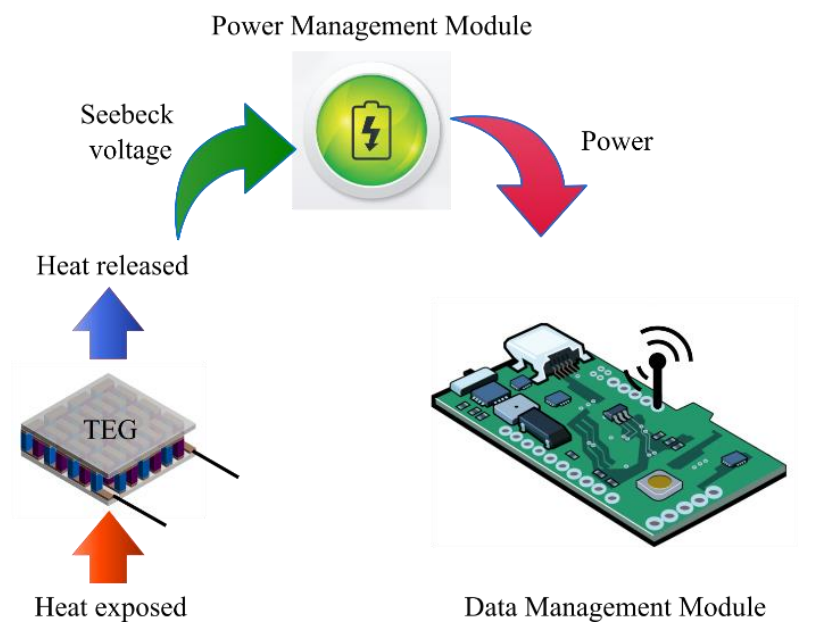

Fig. 1 Illustration of main blocks and powering principle of the thermoelectric WSN node.

The temperature difference between the TEG's sides of $\approx 10^{\circ} \mathrm{C}$ produces Seebeck voltage of a few tens of $\mathrm{mV}$. This is insufficient for the operation of electronic devices, and the generated Seebeck voltage is introduced into the power management module, 
which enables continuous supply of the data management module. Excess energy is routed to the storage, typically super capacitor, so it could be used when the temperature difference become too low for efficient energy conversion. The data management module consists of sensors, microcontroller and RF transceiver for data acquisition, processing and transmission, respectively.

Commercial TEGs are available as compact devices, in the form of an array of thermocouples, sandwiched between the two ceramic plates, as illustrated in Fig 2(a) and (b). Materials used for the thermocouples are n- and p-type semiconductor alloys characterized by Seebeck coefficients of the opposite sign. These pillar-like shaped materials are called legs, and copper electrodes are used for their interconnection. The electrical connection of the thermocouples is serial, while the thermal is parallel. In the case analyzed here, the TEG is incorporated into a WSN node between two aluminumcore printed circuit boards (PCBs), the sensor is located on the bottom one, while the data management module is on the inner side of the top one. Thermally insulating foam fills the gap between the plates. In order to maintain a temperature difference across the TEG, a heatsink is mounted onto the top of the structure, as shown in Fig. 2(c). Although a detailed description of the node construction can be found in [9] the analyzed structure has a couple of differences. Many applications in environmental monitoring require outdoor use, so the WSN node should be sealed. Also, in outdoor conditions, temperature reversal between the plates is likely to occur and the power management module should be designed using auto-polarity circuits [13].

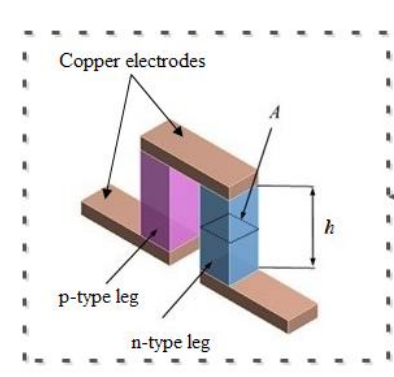

(a)

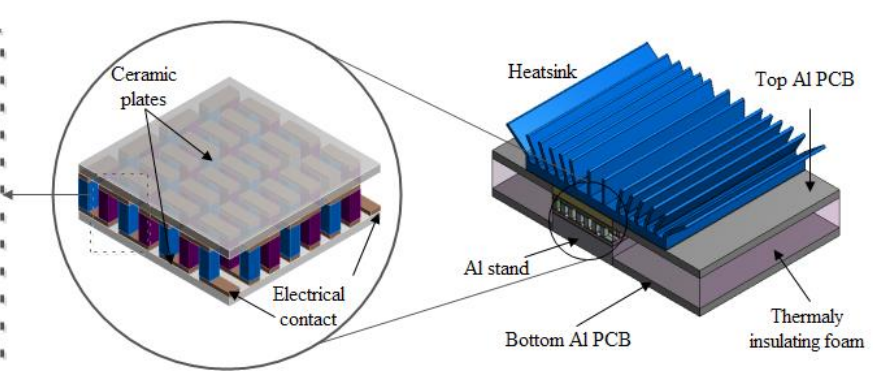

(b)

(c)

Fig. 2 Structure of: (a) thermocouple; (b) thermoelectric generator; (c) wireless sensor network node.

When exposed to the temperature difference across its sides, the TEG generates Seebeck voltage:

$$
V_{G}=N \alpha_{p n} \beta \Delta T_{T E G}
$$

Equation (1) takes into account characteristic parameters of the TEG: number of thermocouples $N$, overall Seebeck coefficient for the thermocouple $\alpha_{p n}$, and correction coefficient $\beta$ due to a finite thermal conductance of the ceramic plates [14]. If the bottom side of the TEG is kept on the temperature $T_{\text {hot }}$ and the top side on the temperature $T_{\text {cold }}$, then:

$$
\Delta T_{T E G}=T_{\text {hot }}-T_{\text {cold }} \text {. }
$$


The power management module appears as a load to the TEG, thus forming an electrical circuit with load current $I_{L}$, as shown in Fig. 3. In addition, the TEG is characterized by its internal electrical resistance:

$$
R_{T E G}=\frac{2 N \rho h}{A},
$$

where $\rho=\rho_{n}=\rho_{p}$ is the electric resistivity of semiconductor alloys, while $h$ and $A$ are the length and cross sectional area of the thermocouple leg, respectively (Fig. 2). Proper operation of the WSN node requires a stable load voltage $V_{L}$, the value of which needs to be determined.

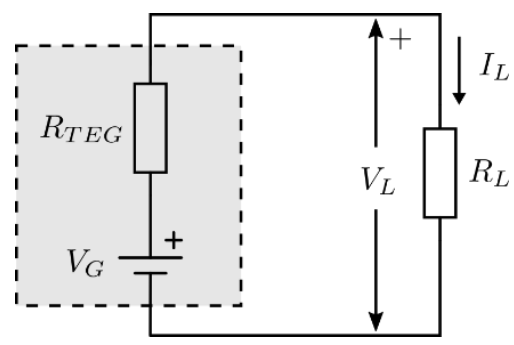

Fig. 3 Equivalent electric circuit of a TEG with a load.

Several analytical models with different level of complexity are available for the thermal and electrical characterization of the TEG [14-18]. Although proven to be accurate for standalone devices, the models cannot take into account complex thermal conditions when the TEG is built into the WSN node $[10,11]$. The complexity of the analysis increases even further by including non-stationary thermal effects, like air flow over the WSN node. Therefore, a three-dimensional (3D) numerical simulation is used in order to estimate dependence of the load voltage on these parameters.

\section{RESULTS AND DISCUSSION}

For the structure of the WSN node from Fig. 2(c), convection from external surfaces to the ambient was identified as a dominant mechanism of the heat release (transfer). According to the Newton's law of cooling, rate of the heat transfer by convection is $[19,20]$ :

$$
q_{c}=\bar{h}_{c} A_{s}\left(T_{s}-T_{a}\right),
$$

where $A_{s}$ is the area of the heat transfer surface, $\bar{h}_{c}$ is the average convection heat transfer coefficient over the surface, while $T_{s}$ and $T_{a}$ are temperatures of the surface and of the fluid (ambient) far away from the surface, respectivelly. Convection can be simulated either by employing computational fluid dynamics (CFD) or by making an assumption of how the heat will leave the volumes of interest. The CFD approach [21] automatically calculates values of every heat transfer coefficient as a function of the corresponding surface temperature, and is known to give the most accurate results. However, for complex geometries it is computationally taxing because it requires an additional fluid domain and external coupling between the CFD and the thermal-electrical solvers, and 
also may be difficult to set up without an extensive knowledge of the underlying numeric. A simpler approach, adopted in this paper, is to assume average values of the heat transfer coefficients (also called film coefficients) and assign them to the appropriate surfaces as initial boundary conditions in thermal-electric simulation. By knowing the shape (plate, cylinder), orientation (horizontal, vertical, inclined), and dimension of the surface, values of the coefficients can be calculated using convective correlations widely available in the literature $[19,20,22]$. These correlations are developed for both free and forced convection, where the latter accounts for fluid velocity. Note that in either case material properties are evaluated at film temperature $T_{f}=\left(T_{s}+T_{a}\right) / 2$.

In this study, three commercial TEGs with parameters listed in Table 1 were considered.

Table 1 Characteristic parameters of the considered TEGs.

\begin{tabular}{lccc}
\hline Parameter & \multicolumn{2}{c}{ Manufacturer part No. } \\
\cline { 2 - 4 } & $\begin{array}{c}\text { MCPE- } \\
071-10-15 \\
\text { (TEG1) }\end{array}$ & $\begin{array}{c}\text { CP 10,31,08 } \\
\text { (TEG2) }\end{array}$ & $\begin{array}{c}\text { CP 08,31,06 } \\
\text { (TEG3) }\end{array}$ \\
\hline Maximum temperature difference $\Delta T_{\max }\left({ }^{\circ} \mathrm{C}\right)$ & 72 & 67 & 67 \\
Maximum cooling power $(\mathrm{W})$ & 16.5 & 5.3 & 4.5 \\
Maximum current at $\Delta T_{\max }(\mathrm{A})$ & 3.2 & 2.5 & 2.1 \\
Maximum voltage at $\Delta T_{\max }(\mathrm{V})$ & 8.8 & 3.8 & 3.7 \\
Number of thermocouples $N$ & 71 & 31 & 31 \\
External dimensions $L \times W \times H(\mathrm{~mm})$ & $20 \times 20 \times 3.8$ & $15 \times 15 \times 3.8$ & $12 \times 12 \times 3.3$ \\
Area of the TEG $\left(\operatorname{mm}{ }^{2}\right)$ & 400 & 225 & 144 \\
Thermocouple leg cross sectional area $A\left(\mathrm{~mm}^{2}\right)$ & 1 & 1 & 0.64 \\
Thermocouple leg length $h(\mathrm{~mm})$ & 1.5 & 2.0 & 1.5 \\
Seebeck coefficient $\alpha_{p n}\left(\mu \mathrm{V} /{ }^{\circ} \mathrm{C}\right)$ & 396 & 378 & 378 \\
Temperature coefficient of $\alpha_{p n}\left(1 /{ }^{\circ} \mathrm{C}\right)$ & & $1.9 \cdot 10^{-3}$ & 1.7 \\
Thermocouple thermal conductivity $\lambda\left(\mathrm{W} / \mathrm{m}^{\circ} \mathrm{C}\right)$ & 1.5 & 1.7 & 10.6 \\
Thermocouple resistivity $\rho(\mu \Omega \mathrm{m})$ & 11.4 & 10.6 & 1.54 \\
Internal electrical resistance $R_{T E G}(\Omega)$ & 2.43 & 1.31 & \\
\hline
\end{tabular}

A simulation was carried out in ANSYS by numerical solving of thermal and electric conduction equations [23]. Material properties with appropriate values were assigned to each part of the WSN node, as described in [10]. Joule heating, Seebeck, Peltier, and Thomson effects are taken into account simultaneously, while the radiation effect is neglected [24, 25]. A hot plate is used as a heat source, so the outer side of the bottom PCB is kept at a constant temperature. For a specified hot plate temperature $T_{h}$ and ambient temperature $T_{a}$, simulation using heat transfer coefficients for free convection gives distributions of temperature within the WSN node and the electric potential inside the TEG cells, as shown in Fig. 4. 


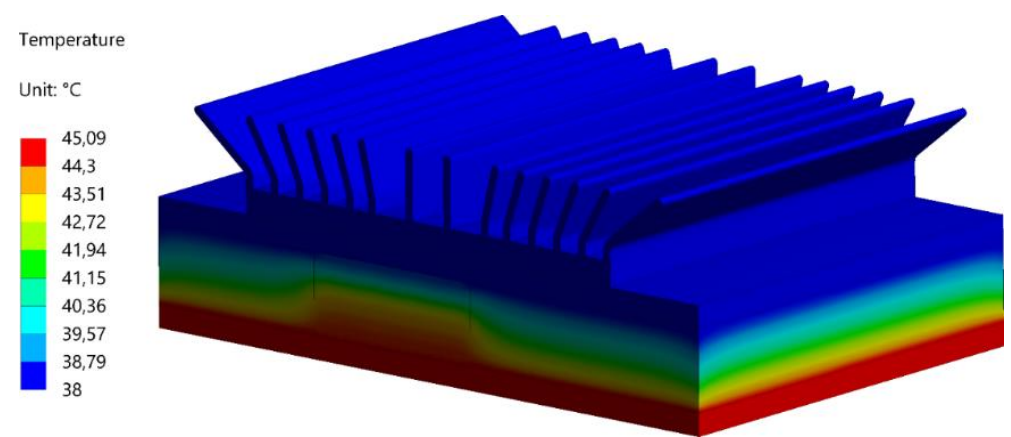

(a)

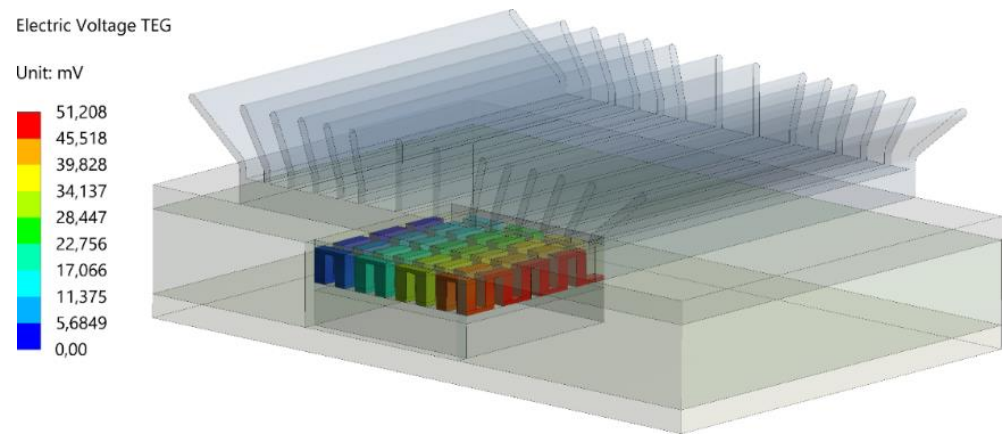

(b)

Fig. 4 Free convection: (a) Temperature distribution within the WSN node with TEG2;

(b) Electric potential distribution in the TEG cells; $T_{h}=45^{\circ} \mathrm{C}, T_{a}=30^{\circ} \mathrm{C}, I_{L}=12 \mathrm{~mA}$.

Temperature difference $\Delta T_{T E G}$ defined by (2) can be extracted from the distribution shown in Fig. 4(a), while the generated Seebeck voltage $V_{L}$ is observed from Fig. 4(b) as a potential difference between the outermost electrical contacts depicted in Fig. 2. Because the WSN node requires $V_{L(\mathrm{~min})}=40 \mathrm{mV}$ for stable and reliable operation, the load current $I_{L}$ is fixed at $12 \mathrm{~mA}$, the value extracted from the datasheet of the power management circuit [26]. The WSN node construction allows temperature distribution within the top PCB and heatsink to be uniform (Fig. 4(a)). Due to the similarities of the materials, heat transfer coefficients have almost the same dependence on the film temperature, thus leaving the difference in their dependencies only on the characteristic lengths of various heatsink and top PCB surfaces [20]. Therefore, from the user's point of view, it can be more convenient to observe temperature difference between the hot plate and the ambient [12]:

$$
\Delta T_{a}=T_{h}-T_{a},
$$

rather than extracting $\Delta T_{T E G}$. The design of experiment for free convection is composed using $T_{h}$ and $T_{a}$ as parameters. The ambient temperature is kept within the range $10-35^{\circ} \mathrm{C}$ and the hot plate temperature is adjusted to obtain temperature difference $\Delta T_{a}$ in the range of $10-35^{\circ} \mathrm{C}$. Response surface for TEG2 is shown in Fig. 5, while qualitatively similar results are obtained for the other two TEGs. 


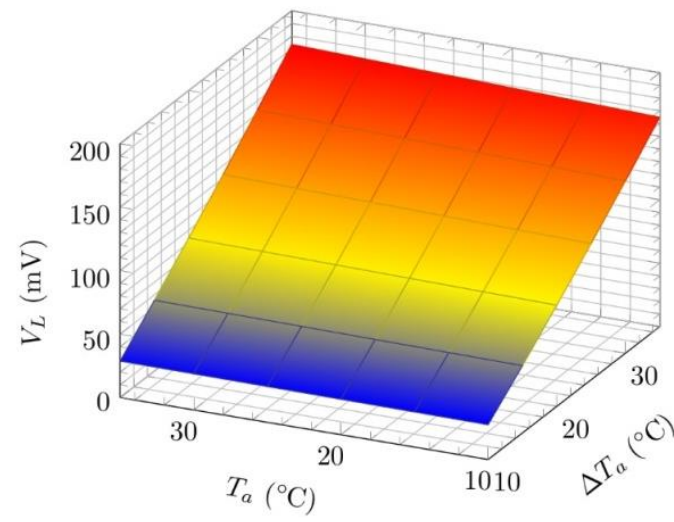

Fig. 5 Load voltage vs. ambient temperature and temperature difference $\Delta T_{a}$ from (5) for WSN node with TEG2 under free convection; $I_{L}=12 \mathrm{~mA}$

It can be observed that the load voltage dependence on the ambient temperature is very weak (relative change $\approx 5 \%$ in the considered range of $T_{a}$ ). This is due to the fact that $V_{L}$ is governed primarily by the temperature difference between the hot and cold sides of the TEG, and not by the ambient temperature. On the other hand, dependence on $\Delta T_{a}$ is pronounced and nearly linear. If the simulation is carried out for the open circuit condition $\left(I_{L}=0\right)$, then voltage $V_{G}$ can be correlated to $\Delta T_{a}$ as:

$$
V_{G} \simeq \bar{\gamma} \Delta T_{a},
$$

where $\bar{\gamma}$ is a proportionality factor averaged over the considered temperature range.

From the circuit shown in Fig. 3, (1) and (5) the load voltage is:

$$
V_{L} \simeq \bar{\gamma} \Delta T_{a}-R_{T E G} I_{L} .
$$

For the temperature ranges considered here, one can neglect to a first approximation temperature dependence of $\rho$, and constant values for $R_{T E G}$ given in Tab. 1 may be used. For the known load current, and $\bar{\gamma}$ determined by couple of measurements or simulations, $V_{L}$ can be predicted from (7). For example, for the WSN node with TEG2 the value $\bar{\gamma}=5.1 \mathrm{mV} /{ }^{\circ} \mathrm{C}$ is extracted. Using this value and $I_{L}=12 \mathrm{~mA}$, the approximate values of $V_{L}$ calculated on the basis of (7) deviate from those obtained by the simulation by a maximum of $10 \%$.

For forced convection, in addition to $T_{h}$ and $T_{a}$, air velocity is changed from $0.5 \mathrm{~m} / \mathrm{s}$, up to $3 \mathrm{~m} / \mathrm{s}$ (light breeze). Unducted air flow along parallel plates of the heatsink fins is assumed, as shown in Fig. 6.

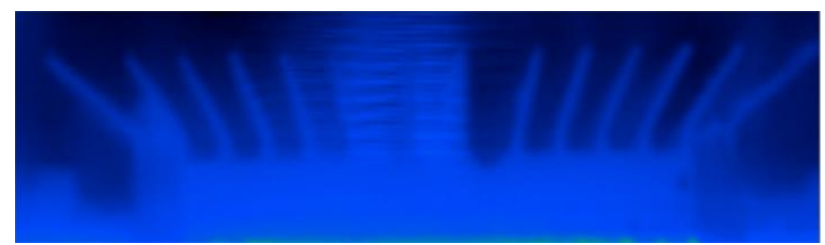

Fig. 6 Thermal image showing heatsink and the top PCB under unducted air flow. 
Obtained dependencies of the load voltage on the air velocity for WSN node with TEG1 and TEG2 are shown in Figs. 7 and 8, illustrating expected increase of the load voltage due to forced convection.

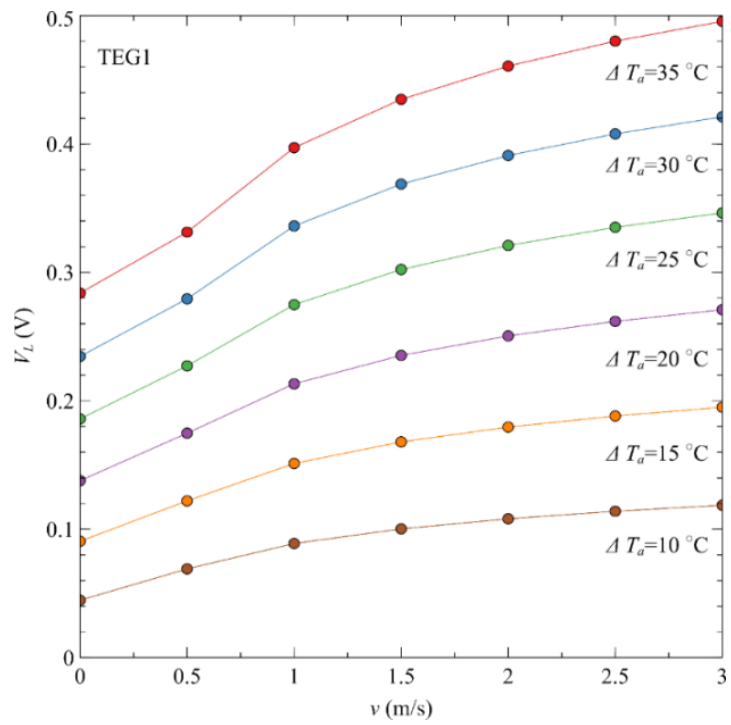

Fig. 7 Forced convection: Load voltage vs. air velocity for the WSN node with TEG1; $T_{h}=45^{\circ} \mathrm{C}, I_{L}=12 \mathrm{~mA}$.

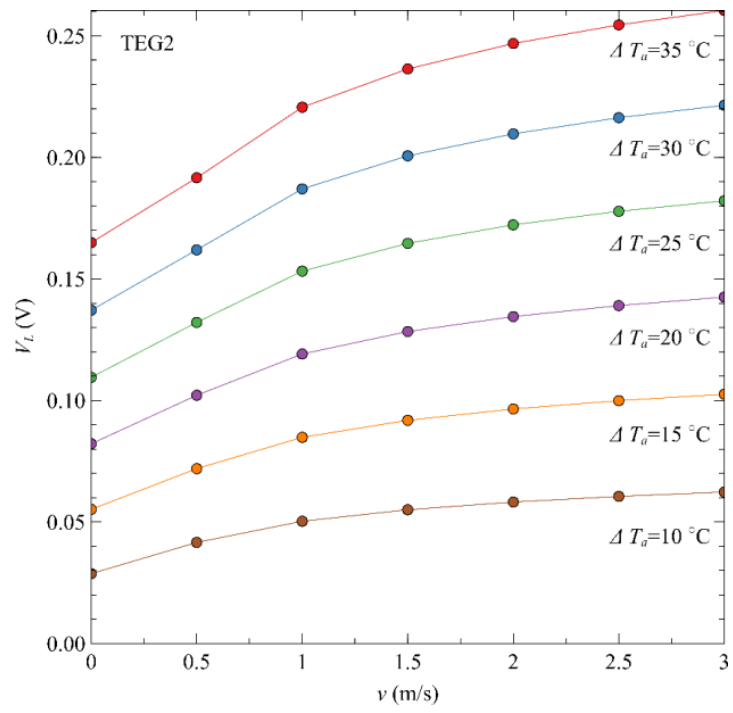

Fig. 8 Forced convection: Load voltage vs. air velocity for the WSN node with TEG2; $T_{h}=45^{\circ} \mathrm{C}, I_{L}=12 \mathrm{~mA}$. 
While qualitative dependencies are similar, quantitative values of the load voltage are higher for TEG1, primarily due to larger number of thermocouples. Note that results for TEG3 are very close to those obtained for TEG2 due to similarity of their characteristic parameters, as listed in Tab. 1. Data from Fig. 8 can be rearranged in order to get better insight into quantitative changes of the load voltage under forced convection, relative to free convection, i.e.:

$$
\delta V_{L} \simeq \frac{V_{L(v)}-V_{L(0)}}{V_{L(0)}} \cdot 100(\%)
$$

where $V_{L(v)}$ and $V_{L(0)}$ are load voltages obtained for forced and free convection $(v=0 \mathrm{~m} / \mathrm{s})$, respectively. As illustrated in Fig. 9 increase of the load voltage is more pronounced for lower $\Delta T_{a}$. However, for a given, $\Delta T_{a}$ both Figs. 8 and 9 show that a major benefit is given to air velocity at about $1 \mathrm{~m} / \mathrm{s}$, while for higher velocities $\delta V_{L}$ tends to saturate. This is primarily due to the thermal resistance of the heatsink $R_{t h(h s)}$, which exhibits a steeper decrease for velocities up to $1 \mathrm{~m} / \mathrm{s}$ than for those above [27].

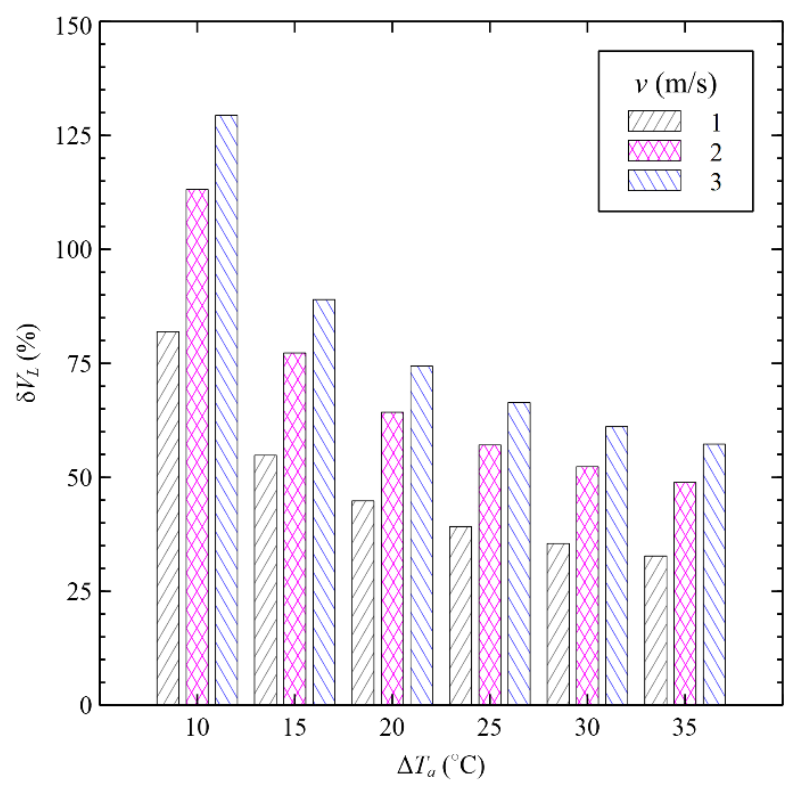

Fig. 9 Load voltage change under forced convection relative to free convection vs. $\Delta T_{a}$ for the WSN node with $T_{h}=45^{\circ} \mathrm{C}, I_{L}=12 \mathrm{~mA}$.

A comparison between simulated and experimental values of $V_{L}$ is shown in Tab. 2 . Disagreements are due to the fact that simulation does not take into account surface roughness and incomplete fulfilment of the thermal insulation between the PCBs, and also leakage currents, which inevitably occur in the real circuit. 
Table 2 Simulated vs. experimental data for the WSN node with TEG2 (unducted flow, $\Delta T_{a}=18^{\circ} \mathrm{C}, I_{L}=12 \mathrm{~mA}$ ).

\begin{tabular}{ccccc}
\hline$v(\mathrm{~m} / \mathrm{s})$ & & 0 & 1.25 & 2.5 \\
\hline \multirow{2}{*}{$V_{L}(\mathrm{mV})$} & simulation & 75 & 110 & 122 \\
& experiment & 70 & 100 & 110 \\
\hline
\end{tabular}

It is of practical interest to know the minimal temperature difference $\Delta T_{a(\min )}$ required to supply the WSN node at a fixed load condition, as shown in Fig. 10.

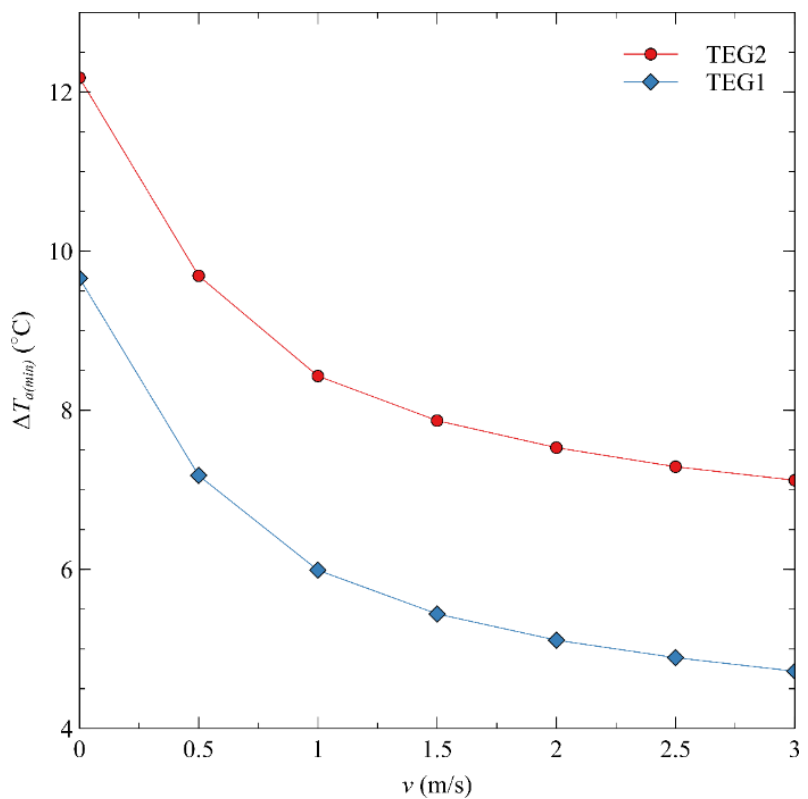

Fig. 10 Minimal $\Delta T_{a}$ required to produce $V_{L(\min )}=40 \mathrm{mV}$ at $T_{a}=30^{\circ} \mathrm{C}$ and $I_{L}=12 \mathrm{~mA}$ for WSN nodes with TEG1 and TEG2.

In general, $\Delta T_{a(\min )}$ decreases as air velocity $v$ increases, and qualitatively follows dependence of $R_{t h(h s)}$ on $v$ :

$$
\Delta T_{a(\min )}(v) \propto R_{t h(h s)}(v)
$$

However, although heatsink manufacturers specify $R_{t h(h s)}(v)$, proportionality factor in (9) can not be determined analytically because it also depends on the characteristic parameters of the TEG (Tab. 1). Another difficulty arises from the fact that the heatsink base is effectively extended by the top PCB, thus leading to the deviation from the specified $R_{t h(h s)}(v)$ dependence. Therefore, $R_{t h(h s)}$ can be viewed as a part of the overall thermal resistance of the node, which would depend on many physical and geometrical parameters. For the WSN node considered here, $\Delta T_{a(\min )}$ at $1 \mathrm{~m} / \mathrm{s}$ will be reduced by approximately one-third relative to the value for stagnant air. This is data of practical importance, because such a condition is most likely to occur in a real operating environment. 


\section{CONCLUSION}

In this paper, the influence of ambient conditions on the performance of the thermoelectric wireless sensor node was investigated. Free and forced convection cases were analyzed by using three-dimensional fully coupled electro--thermal simulation of the complete node, by applying convective correlations describing heat transfer between the node and the ambient. It was found that the change of ambient temperature within the range $10-35^{\circ} \mathrm{C}$ has minor effect on the voltage $V_{L}$ generated by the thermoelectric generator inside the node, as long as the temperature difference between the hot side of the node and the ambient $\Delta T_{a}$ is maintained. It is shown that it is more feasible to observe $\Delta T_{a}$ rather than the temperature difference between the sides of the thermoelectric generator. For free convection, a simple, open-circuit based approximation for estimation of $V_{L}$ as a function of $\Delta T_{a}$ is proposed. For forced convection, quantitative changes of $V_{L}$ for air velocities in the range $0.5-3 \mathrm{~m} / \mathrm{s}$ are obtained for three thermoelectric generators. It has been established that the value of $V_{L}$ increases as the thermal resistance of the node decreases, as compared to the case of natural convection. However, due to the complexity of the structure, quantitative changes are obtained by the simulation.

Acknowledgement: This work was supported in part by the Serbian Ministry of Education, Science and Technological Development under Grant TR32026 and in part by Ei PCB Factory, Niš, Serbia.

\section{REFERENCES}

1. Handbook of Energy Harvesting Power Supplies and Applications (eds Mateu L., Pollak M. and Spies P.) (CRC Press, 2015).

2. White R., Nguyen D.-S.,Wu Z. andWright P., Atmospheric Sensors and Energy Harvesters on Overhead Power Lines, Sensors, Vol. 18, p. 114 (Jan. 2018).

3. Olatinwo S. and Joubert T.-H., Optimizing the Energy and Throughput of a Water-Quality Monitoring System, Sensors, 18, 1198 (Apr. 2018).

4. Prijić A., Vračar Lj., Pavlović Z., Kostić Lj. and Prijić Z., The Effect of Flat Panel Reflectors on Photovoltaic Energy Harvesting in Wireless Sensor Nodes Under Low Illumination Levels, IEEE Sensors Journal, Vol. 15, pp. 7105-7111 (Dec. 2015).

5. Vračar Lj., Prijić A., Nešić D., Dević S. and Prijić Z. Photovoltaic Energy Harvesting Wireless Sensor Node for Telemetry Applications Optimized for Low Illumination Levels, Electronics, Vol. 5, p. 26 (June 2016).

6. Woias P., Schule F., Baumker E., Mehne P. and Kroener M. Thermal Energy Harvesting from Wildlife, Journal of Physics: Conference Series, Vol. 557, p. 012084 (2014).

7. Mehne P., Lickert F., Baumker E., Kroener M. and Woias P. Energy autonomous wireless sensor nodes for automotive applications, powered by thermoelectric energy harvesting, Journal of Physics: Conference Series, Vol. 773, p. 012041 (Nov. 2016).

8. Nesarajah M. and Frey G. Optimized Design of Thermoelectric Energy Harvesting Systems for Waste Heat Recovery from Exhaust Pipes, Applied Sciences, Vol. 7, p. 634 (June 2017).

9. Prijić A., Vračar Lj., Vučković D., Milić D. and Prijić Z. Thermal energy harvesting wireless sensor node in aluminum core PCB technology, IEEE Sensors Journal, Vol. 15, pp. 337-345 (2015).

10. Milić D., Prijić A., Vračar Lj. and Prijić Z. Characterization of commercial thermoelectric modules for application in energy harvesting wireless sensor nodes, Applied Thermal Engineering, Vol. 121, pp. 74 82 (July 2017).

11. Prijić A., Marjanović M., Vračar Lj., Danković D. and Prijić Z. A Steady-State SPICE Modeling of the Thermoelectric Wireless Sensor Network Node in Proc. IcETRAN 2017 (Kladovo, Serbia, 2017), pp. MOI2.3.1-MOI2.3.6.

12. Prijić Z., Vračar Lj. and Prijić A. Design and Characterization of Thermoelectric Energy Harvesting Systems for Wireless Sensor Network Nodes in Proc. IcETRAN 2018 (Palić, Serbia, June 2018), pp. MOI1.1.1-MOI1.1.7. 
13. Salerno D. Ultralow Voltage Energy Harvester Uses Thermoelectric Generator for Battery-Free Wireless biosensors, Journal of Analog Innovation, Vol. 20, pp. 1-11 (2010).

14. Dalola S. et al. Characterization of Thermoelectric Modules for Powering Autonomous Sensors, IEEE Transactions on Instrumentation and Measurement, Vol. 58, pp. 99-107 (Jan. 2009).

15. Palacios R., Arenas A., Pecharromán R. and Pagola F. Analytical procedure to obtain internal parameters from performance curves of commercial thermoelectric modules, Applied Thermal Engineering, Vol. 29, pp. 3501-3505 (2009).

16. Dziurdzia P. Modeling and Simulation of Thermoelectric Energy Harvesting Process in Sustainable Energy Harvesting Technologies - Past, Present and Future (InTech, Dec. 2011).

17. Carmo J. et al. Characterization of thermoelectric generators by measuring the load-dependence behavior, Measurement, Vol. 44, pp. 2194-2199 (Dec. 2011).

18. Siouane S., Jovanović S. and Poure P. Equivalent Electrical Circuits of Thermoelectric Generators under Different Operating Conditions, Energies, Vol. 10, p. 386 (Mar. 2017).

19. Kreith F., Manglik R. and Bohn M. Principles of Heat Transfer 7th ed. (Cengage Learning, 2011).

20. Incropera F., DeWitt D., Bergman T. and Lavine A. Fundamentals of heat and mass transfer 6th ed. (Wiley, 2007).

21. ANSYS Inc. ANSYS CFX, 2018. https://www.ansys.com /products/fluids/ansys-cfx.

22. Welty J., Wicks C., Wilson R. and Rorrer G. Fundamentals of Momentum, Heat, and Mass Transfer 5th ed. (Wiley, 2008)

23. ANSYS Inc. Multiphysics simulation, 2018. https://www.ansys.com/products/platform/multiphysicssimulation.

24. Li W. et al. Multiphysics Simulations of a Thermoelectric Generator, Energy Procedia, Vol. 75, pp. 633638 (2015).

25. Bjørk R., Christensen D., Eriksen D. and Pryds N. Analysis of the internal heat losses in a thermoelectric generator, International Journal of Thermal Sciences, Vol. 85, pp. 12-20 (Nov. 2014).

26. LTC3108 ultralow voltage step-up converter and power manager Datasheet. Linear Technology Corporation, 2010. http://www.linear.com.

27. ATS-50350B-C1-R0 BGA Heat Sink Datasheet. Advanced Thermal Solutions, Inc., 2013. https://www.qats.com.

\section{UTICAJ AMBIJENTALNIH USLOVA NA PERFORMANSE TERMOELEKTRIČNOG ČVORA BEŽIČNE SENZORSKE MREŽE}

Rad analizira uticaj temperature ambijenta i brzine strujanja vazduha na vrednost napona termoelektričnog generatora koji napaja čvor bežične senzorske mreže. Struktura čvora je numerički simulirana korišćenjem spregnutog elektro-termalnog modela i konvektivnih korelacija. Rezultati pokazuju da je uticaj temperature ambijenta zanemarljiv sve dok se razlika temperatura između tople i hladne strane čvora održava konstantnom. Kada nema strujanja vazduha zavisnost generisanog napona od razlike temperatura se može odrediti iz uslova otvorenog kola, a kasnije aproksimativno primeniti $i$ za kolo sa opterećenjem. Kada postoji strujanje vazduha, ova zavisnost je određena termičkom otpornošću hladnjaka i karakterističnim parametrima termoelektričnog generatora.

Ključne reči: termoelektrični generator, čvor bežične senzorske mreže, prikupljanje energije 